\title{
Study on Inclusions in Almandine Garnet from Vemireddipalle Area, Krishna District, Andhra Pradesh, India
} Nazia Sultana

\author{
Research Scholar, Department of Geology, Acharya Nagarjuna University, Andhra Pradesh, India
}

\begin{abstract}
Almandine Garnet is purplish red in colour. The mineral samples are collected from Vemireddipalle area, Krishna District, Andhra Pradesh. Dataset/points are examined using EPMA. It is found that $\mathrm{P}_{2} \mathrm{O}_{5}(29.34 \%)$ and $\mathrm{Ce}_{2} \mathrm{O}_{3}(22.47 \%)$ are abundant and the major oxides support the presence of Monazite inclusion. The high concentration of $\mathrm{ZrO}_{2}$ and $\mathrm{SiO}_{2}$ helped to confirm the other inclusion as Zircon.
\end{abstract}

Keywords : Almandine Garnet, Inclusion, Monazite, Zircon

\section{INTRODUCTION}

The word garnet comes from the $14^{\text {th }}$-century Middle English word gernet, meaning 'dark red'. It is derived from the Latin granatus, from granum ('grain, seed') (https://en.wikipedia.org/wiki/Garnet). Garnets have been valued as gemstones for more than 5000 years (https://www. wikigempedia.com/garnet.html). The mineral samples are collected from Vemireddipalle area, Krishna District, Andhra Pradesh, India.

\section{Uses}

$>$ Garnets were used by Egyptian's jewellery as early as 3100BC. Also, garnet has been rose-cut, used as Bohemian garnet, since the Victorian era (https://www. wikigempedia.com/garnet.html).

$>$ Garnets were used extensively in the historical bead-making industry of Arikamedu in Tamilnadu state (Gilg et al., 2018).

$>$ Garnets are of importance as a jewel in the bearings of watches and scientific instruments.

$>$ This mineral is used as an abrasive, either as garnet sandpaper or as a loose-grained powder for grinding and polishing plate glass (Jones, 1974).
Garnet, a common replacement for silica sand in sandblasting (https://www. reade.com/products/).

\section{Previous studies}

Inclusions present in Almandine Garnet were reported in the literature by various authors.

The study on Garibpet samples revealed the presence of quartz, zircon crystals, brownish goethite-bearing fracture, monazite, zircon and rutile were observed (Gilg et al., 2018). Bugoi et al., (2016) identified ilmenite, rutile, monazite, sillimanite and zircon inclusions in peitroasa and cluj-someseni treasures and Apahida samples. Monazite is reported from South India and Sri Lanka by Horvath and Bendo (2011). Thoresen and Schmetzer (2013) observed zircon crystals, monazite with strain halos, twophase inclusions, rutile or ilmenite needles and apatite crystals in Almandine Garnet. Apatite, zircon, ilmenite, monazite, calcite and quartz inclusions were identified by Calligaro et al., (2002) from different countries (Indian, Ceylonese and Bohemian deposits). Wendt et al., (1993) reported quartz, apatite, zircon and rutile inclusions from Oman Mountains. 
The aim of the present study is to identify the Inclusions of Almandine Garnet gemstone from Vemireddipalle area, Krishna district, Andhra Pradesh, India.

\section{METHODOLOGY}

Fifteen dataset/points are examined by using Electron Probe Micro Analyses (EPMA). The samples are medium to dark purplish red in colour. By EPMA the following oxides were measured, i.e., $\mathrm{P}_{2} \mathrm{O}_{5}, \mathrm{Ce}_{2} \mathrm{O}_{3}$, $\mathrm{ThO}_{2}, \mathrm{La}_{2} \mathrm{O}_{3}, \mathrm{Nd}_{2} \mathrm{O}_{3}, \mathrm{CaO}, \mathrm{Pr}_{2} \mathrm{O}_{3}, \mathrm{Y}_{2} \mathrm{O}_{3}, \mathrm{SiO}_{2}, \mathrm{SmO}$, $\mathrm{Gd}_{2} \mathrm{O}_{3}, \mathrm{PbO}, \mathrm{UO}_{2}, \mathrm{FeO}$ and $\mathrm{ZrO}_{2}$. Details are presented under Results and discussion.

\section{RESULTS AND DISCUSSION}

In the study area, monazite and zircon inclusions are identified from the Almandine garnet samples. The details are presented in this section.

\section{Monazite}

From the EPMA analyses of five points, it is observed that the oxides of $\mathrm{P}_{2} \mathrm{O}_{5}, \mathrm{Ce}_{2} \mathrm{O}_{3}, \mathrm{ThO}_{2}, \mathrm{La}_{2} \mathrm{O}_{3}, \mathrm{Nd}_{2} \mathrm{O}_{3}$ are present in higher quantities (Table 1 and Figure 1). $\mathrm{P}_{2} \mathrm{O}_{5}$ varies in between $26.90 \mathrm{wt} \%$ and 29.34, followed by $\mathrm{Ce}_{2} \mathrm{O}_{3}$ (21.95 to 22.47). $\mathrm{ThO}_{2}$ lies between 16.84 to $19.58, \mathrm{La}_{2} \mathrm{O}_{3}, 11.54$ to 12.09 and $\mathrm{Nd}_{2} \mathrm{O}_{3}$, from 8.62 to 8.89. $\mathrm{CaO}, \mathrm{Pr}_{2} \mathrm{O}_{3}, \mathrm{Y}_{2} \mathrm{O}_{3}, \mathrm{SiO}_{2}$, $\mathrm{SmO}, \mathrm{Gd}_{2} \mathrm{O}_{3}, \mathrm{PbO}, \mathrm{UO}_{2}, \mathrm{FeO}$ and $\mathrm{ZrO}_{2}$ are present in minor amounts. Based on the concentrations of $\mathrm{P}_{2} \mathrm{O}_{5}$, $\mathrm{Ce}_{2} \mathrm{O}_{3}, \mathrm{ThO}_{2}, \mathrm{La}_{2} \mathrm{O}_{3}$ and $\mathrm{Nd}_{2} \mathrm{O}_{3}$ the inclusion is identified as monazite (Plates 1 and 2).
TABLE 1

EPMA ANALYSIS OF MONAZITE INCLUSIONS

\begin{tabular}{|c|c|c|c|c|c|}
\hline \multirow{2}{*}{ Oxides } & \multicolumn{5}{|c|}{ Data Points } \\
\cline { 2 - 6 } & $\mathbf{1}$ & $\mathbf{2}$ & $\mathbf{3}$ & $\mathbf{4}$ & $\mathbf{5}$ \\
\hline $\mathrm{P}_{2} \mathrm{O}_{5}$ & 29.34 & 28.36 & 27.14 & 26.90 & 28.18 \\
\hline $\mathrm{Ce}_{2} \mathrm{O}_{3}$ & 22.02 & 22.41 & 21.95 & 22.22 & 22.47 \\
\hline $\mathrm{ThO}_{2}$ & 16.84 & 19.58 & 18.64 & 18.87 & 17.46 \\
\hline $\mathrm{La}_{2} \mathrm{O}_{3}$ & 11.93 & 11.89 & 12.03 & 12.09 & 11.54 \\
\hline $\mathrm{Nd}_{2} \mathrm{O}_{3}$ & 8.80 & 8.62 & 8.64 & 8.74 & 8.89 \\
\hline $\mathrm{CaO}$ & 2.60 & 2.98 & 2.75 & 2.84 & 2.70 \\
\hline $\mathrm{Pr}_{2} \mathrm{O}_{3}$ & 1.88 & 2.02 & 2.15 & 1.92 & 2.14 \\
\hline $\mathrm{Y}_{2} \mathrm{O}_{3}$ & 1.85 & 0.11 & 0.12 & 0.14 & 0.50 \\
\hline $\mathrm{SiO}_{2}$ & 1.65 & 2.07 & 1.93 & 1.94 & 2.00 \\
\hline $\mathrm{SmO}^{2} \mathrm{Gd}_{2} \mathrm{O}_{3}$ & 1.52 & 1.16 & 1.17 & 0.88 & 1.24 \\
\hline $\mathrm{PbO}^{2}$ & 0.47 & 0.51 & 0.30 & 0.16 & 0.95 \\
\hline $\mathrm{UO}_{2}$ & 0.76 & 1.05 & 0.52 & 0.57 & 0.41 \\
\hline $\mathrm{FeO}^{2}$ & 0.14 & 0.19 & 0.09 & 1.11 & 0.93 \\
\hline $\mathrm{ZrO}_{2}$ & 0.00 & 0.00 & 0.00 & 0.00 & 1.16 \\
\hline Total $^{2}$ & $\mathbf{1 0 0 . 8 4}$ & $\mathbf{1 0 1 . 4 9}$ & $\mathbf{9 8 . 5 6}$ & $\mathbf{9 8 . 8 0}$ & $\mathbf{1 0 0 . 5 9}$ \\
\hline
\end{tabular}

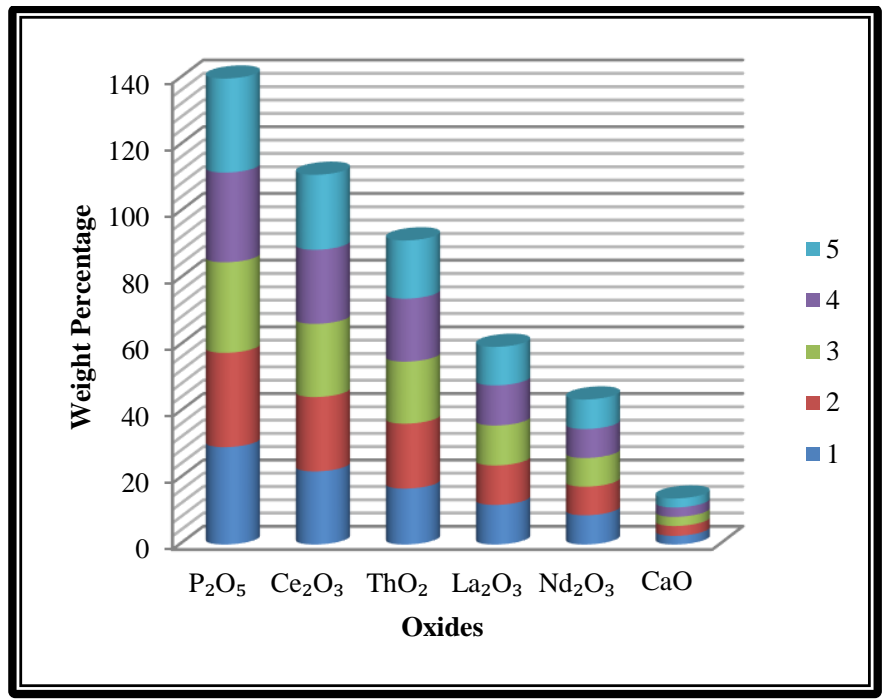

Figure 1 Oxides in Monazite

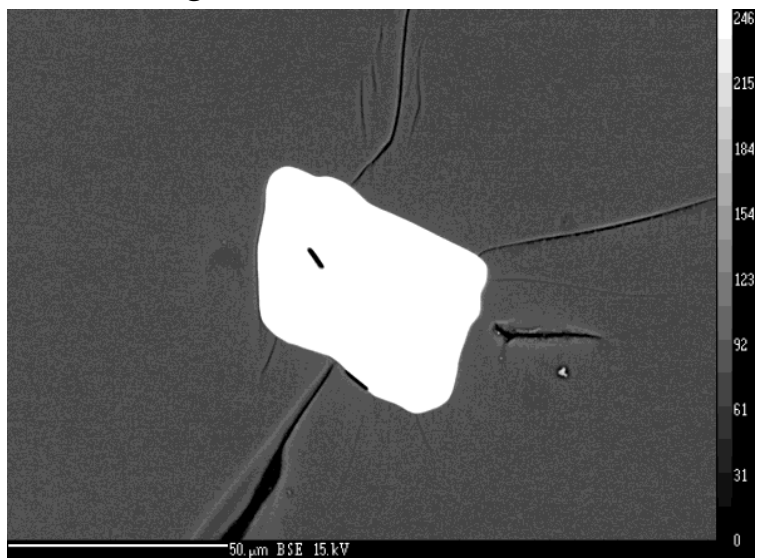

Plate 1 Monazite inclusions in Almandine Garnet 


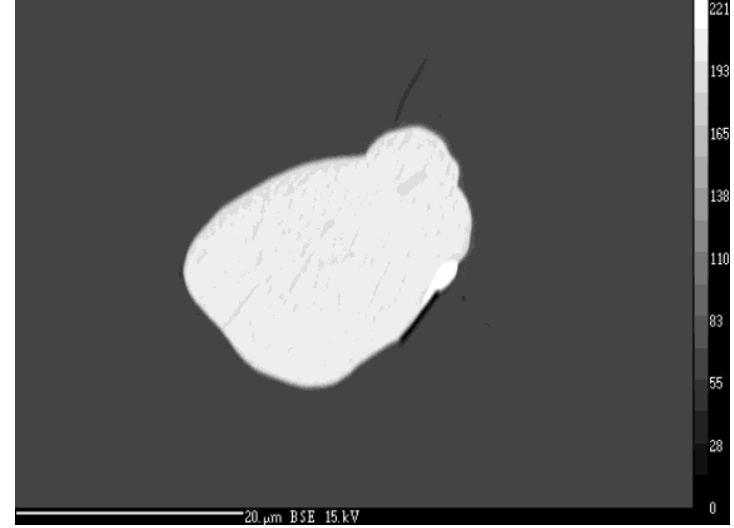

Plate 2 Monazite inclusions in Almandine garnet

\section{Zircon}

$\mathrm{ZrO}_{2}$ varies in between $64.34 \mathrm{wt} \%$ and 66.57 in 10 data set points, at which the study was carried out. $\mathrm{SiO}_{2}$ ranges from 29.68 to 33.19 and it is followed by $\mathrm{FeO}$, which lies between 0.75 and 1.46 . $\mathrm{UO}_{2}$, $\mathrm{P}_{2} \mathrm{O}_{5}, \mathrm{Nd}_{2} \mathrm{O}_{3}, \mathrm{CaO}, \mathrm{Y}_{2} \mathrm{O}_{3}, \mathrm{La}_{2} \mathrm{O}_{3}, \mathrm{Ce}_{2} \mathrm{O}_{3}, \mathrm{Pr}_{2} \mathrm{O}_{3}$, $\mathrm{SmO}, \mathrm{Gd}_{2} \mathrm{O}_{3}$ and $\mathrm{ThO}_{2}$ are noticed in lesser quantities. High concentrations of $\mathrm{ZrO}_{2}$ and $\mathrm{SiO}_{2}$ revealed that the inclusion is zircon (Table 2 and Plates 3 and 4).

Table 2. EPMA analysis of Zircon inclusions

\begin{tabular}{|c|c|c|c|c|c|c|c|c|c|c|}
\hline & \multicolumn{10}{|c|}{ Data Points } \\
\hline Oxides & $\mathbf{1}$ & $\mathbf{2}$ & $\mathbf{3}$ & $\mathbf{4}$ & $\mathbf{5}$ & $\mathbf{6}$ & $\mathbf{7}$ & $\mathbf{8}$ & $\mathbf{9}$ & $\mathbf{1 0}$ \\
\hline $\mathrm{ZrO}_{2}$ & 64.52 & 66.57 & 65.20 & 66.32 & 64.34 & 65.54 & 65.61 & 65.63 & 65.26 & 64.77 \\
\hline $\mathrm{SiO}_{2}$ & 32.84 & 31.03 & 32.33 & 29.68 & 33.19 & 33.11 & 32.49 & 32.46 & 32.54 & 32.64 \\
\hline $\mathrm{FeO}$ & 1.46 & 1.05 & 0.89 & 0.91 & 0.96 & 1.08 & 1.05 & 0.90 & 1.90 & 0.75 \\
\hline $\mathrm{UO}_{2}$ & 0.38 & 0.44 & 0.27 & 0.32 & 0.02 & 0.00 & 0.22 & 0.22 & 0.35 & 0.20 \\
\hline $\mathrm{P}_{2} \mathrm{O}_{5}$ & 0.30 & 0.25 & 0.28 & 0.29 & 0.31 & 0.44 & 0.36 & 0.35 & 0.31 & 0.46 \\
\hline $\mathrm{PbO}_{2}$ & 0.08 & 0.01 & 0.00 & 0.02 & 0.02 & 0.00 & 0.03 & 0.00 & 0.02 & 0.03 \\
\hline $\mathrm{Nd}_{2} \mathrm{O}_{3}$ & 0.06 & 0.05 & 0.00 & 0.00 & 0.00 & 0.00 & 0.00 & 0.00 & 0.00 & 0.00 \\
\hline $\mathrm{CaO} \mathrm{O}$ & 0.02 & 0.00 & 0.01 & 0.00 & 0.00 & 0.01 & 0.01 & 0.00 & 0.04 & 0.00 \\
\hline $\mathrm{Y}_{2} \mathrm{O}_{3}$ & 0.00 & 0.00 & 0.00 & 0.00 & 0.00 & 0.03 & 0.00 & 0.00 & 0.00 & 0.04 \\
\hline $\mathrm{La}_{2} \mathrm{O}_{3}$ & 0.00 & 0.03 & 0.00 & 0.14 & 0.10 & 0.00 & 0.02 & 0.09 & 0.00 & 0.08 \\
\hline $\mathrm{Ce}_{2} \mathrm{O}_{3}$ & 0.00 & 0.06 & 0.00 & 0.06 & 0.02 & 0.09 & 0.08 & 0.10 & 0.00 & 0.00 \\
\hline $\mathrm{Pr}_{2} \mathrm{O}_{3}$ & 0.00 & 0.00 & 0.00 & 0.00 & 0.09 & 0.00 & 0.00 & 0.00 & 0.03 & 0.00 \\
\hline $\mathrm{SmO}_{2}$ & 0.00 & 0.00 & 0.01 & 0.15 & 0.00 & 0.09 & 0.31 & 0.03 & 0.07 & 0.00 \\
\hline $\mathrm{Gd}_{2} \mathrm{O}_{3}$ & 0.00 & 0.00 & 0.03 & 0.18 & 0.04 & 0.00 & 0.00 & 0.20 & 0.00 & 0.00 \\
\hline $\mathrm{ThO}_{2}$ & 0.00 & 0.05 & 0.01 & 0.00 & 0.03 & 0.00 & 0.00 & 0.03 & 0.03 & 0.04 \\
\hline $\mathbf{T o t a l}$ & $\mathbf{9 9 . 6 4}$ & $\mathbf{9 9 . 5 6}$ & $\mathbf{9 9 . 0 3}$ & $\mathbf{9 8 . 0 5}$ & $\mathbf{9 9 . 1 1}$ & $\mathbf{1 0 0 . 3 9}$ & $\mathbf{1 0 0 . 1 9}$ & $\mathbf{9 9 . 9 9}$ & $\mathbf{1 0 0 . 5 3}$ & $\mathbf{9 9 . 0 1}$ \\
\hline
\end{tabular}

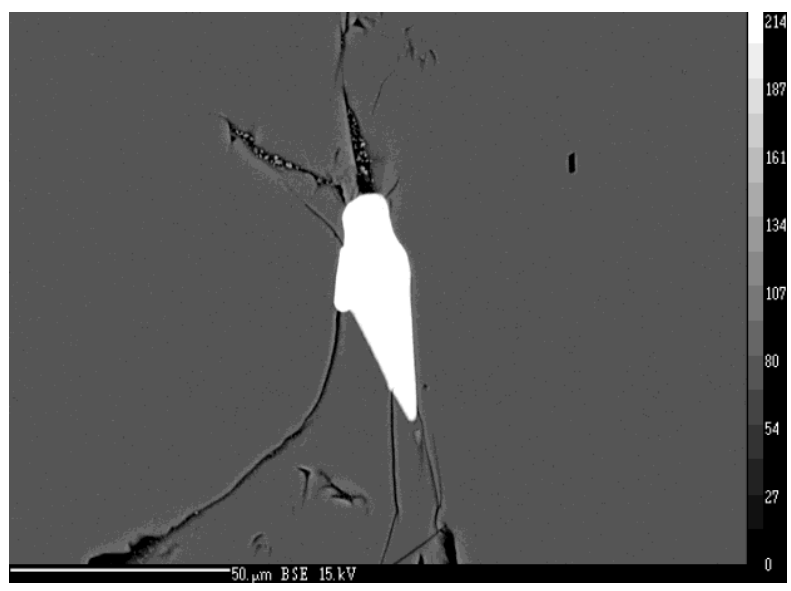

Plate 3 Zircon Inclusions in Almandine Garnet

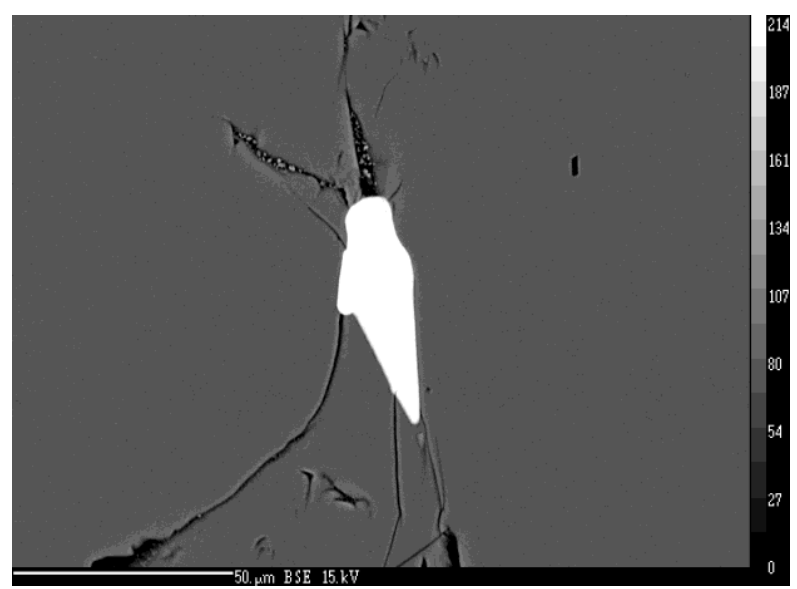

Plate 4 Zircon Inclusions in Almandine Garnet 
The EPMA analyses confirmed the presence of Monazite and Zircon inclusions.

\section{CONCLUSION}

The mineral samples collected from Vemireddipalle area are subjected to EPMA analyses for the identification of inclusions. Based on the EPMA analyses Monazite and Zircon inclusions are identified from the samples.

\section{REFERENCES}

[1]. Bugoi, R., Oanta-Marghitu, R. and Calligaro, T. (2016) IBA investigations of loose garnets from Pietroasa, Apahida and Cluj-Someşeni treasures (5th century AD). Nuclear Instruments and Methods in Physics Research Section B: Beam Interactions with Materials and Atoms, V. 371, pp. 401-406.

[2]. Calligaro, T., Colinart, S., Poirot, J.-P. and Sudres, C. (2002) Combined external-beam PIXE and $\mu$-Raman characterisation of garnets used in Merovingian jewellery. Nuclear Instruments and Methods in Physics Research Section B: Beam Interactions with Materials and Atoms, V. 189(1-4), pp. 320-327.

[3]. Gilg Albert, H., Schmetzer, K. and Schussler, Ulrich (2018) An Early Byzantine Engraved Almandine from the Garibpet Deposit, Telangana State, India: Evidence for Garnet Trade Along the Ancient Maritime Silk Road. Gems and Gemology, V. 54(2), pp. 149-165.

[4]. Horvath, E. and Bendo, Z. (2011) Provenance Study on a Collection of Loose Garnets From a Gepidic Period Grave In Northeast Hungary. Archeometriai Muhely, V. 8(1), pp. 17-32.

[5]. Jones, F. B. (1974) On the Agate Trail. Rocks \& Minerals, V. 49(3), pp. 182-183.

[6]. Thoresen, L. and Schmetzer, K. (2013) Greek, Etruscan and Roman garnets in the antiquities collection of the J.Paul Getty Museum. The Journal of Gemmology, V. 33(7-8), pp.201-222.

[7]. Wendt, A. S., D'Arco, P., Goffe, B., and Oberhansli, R. (1993) Radial cracks around $\alpha-$ quartz inclusions in almandine: Constraints on the metamorphic history of the Oman mountains. Earth and Planetary Science Letters, V. 114(4), pp. 449-461.

[8]. https://en.wikipedia.org/wiki/Garnet

[9]. https://www.wikigempedia.com/garnet.html

[10]. https://www.reade.com/products/garnet-sandgarnet-grain-garnet-powder

\section{Cite this article as :}

Nazia Sultana, "Study on Inclusions in Almandine Garnet from Vemireddipalle Area, Krishna District, Andhra Pradesh, India", International Journal of Scientific Research in Science and Technology (IJSRST), Online ISSN : 2395-602X, Print ISSN : 2395-6011, Volume 6 Issue 4, pp. 82-85, July-August 2019.

Available at doi :

https://doi.org/10.32628/IJSRST196418

Journal URL : http://ijsrst.com/IJSRST196418 